\title{
AVALIAÇÃO MENSAL DE PERDAS DE SOLO NO ALTO CURSO DO RIO AQUIDAUANA-MS
}

\author{
JUCIMARAPARECIDA GUEDES*
}

\author{
DISSERTAÇÃO DE MESTRADO - Programa de Pós-Graduação em Geologia - UFPR \\ DATA DE DEFESA: 29 ago. 2001
}

\begin{abstract}
Neste trabalho são apresentados os resultados alcançados no estudo do processo erosivo laminar no alto curso da bacia do rio Aquidauna-MS, através da aplicação dos parâmetros que compõem a Equação Universal de Perdas de Solo (EUPS), avaliados de forma mensal e multitemporal, num período de 30 anos. Aárea em consideração compreende dois domínios geomorfológicos bem distintos: a Chapada de São Gabriel, onde se concentram as atividades de agricultura intensiva, especialmente cultivo de soja e milho e as áreas circundantes, de relevo mais degradado e dissecado, onde as terras são utilizadas principalmente para pastagem. As épocas do ano em que a erosão laminar é mais intensa foram definidas, principalmente, em função da erosividade $(R)$ da chuva, do fator uso do solo $(C)$, e do fator $P$, ou de práticas conservacionistas. A precipitação anual varia em torno de $1.500 \mathrm{~mm}$, concentrando-se nos meses de janeiro a março. Isto implica no valor encontrado para $C$ em áreas agrícolas, que no período de outubro a março é oito vezes maior que no restante do ano, representando assim uma acentuada variação climática sazonal coincidente com o período de preparo do solo e plantio. Estes dados, junta-
\end{abstract}

mente com os outros fatores $(K, L$ e $S)$ que compõem a EUPS, foram trabalhados em ambiente SIG, e os valores obtidos de $A$ indicaram uma perda anual de solo na bacia estudada de 47.019 toneladas em 1966; 1.421 .798 toneladas em 1985 e 1.356.162 toneladas em 1996 e uma média de solo perdido por hectare de 0.24 toneladas em 1966; 7.52 toneladas em 1985 e 7.17 toneladas em 1996. Sendo que os meses de janeiro, fevereiro, novembro e dezembro, são os meses que concentram maiores perdas de solo, com $52 \%$ para o ano de $66,78 \%$ para o ano de 85 e $71 \%$ para o ano de 96 . Estas perdas ocorrem em áreas com predomínio de solos neossolos litólicos e, principalmente, neossolos quartzarênicos ou na transição deste com latossolos, próximos à escarpa. Com a aplicação da equação de Razão de Perdas de Solo, verificou-se que aproximadamente metade dos sedimentos ficam retidos dentro dos limites da bacia. A principal causa do aumento excessivo de perdas de solo no período estudado está na condição da redução significativa de áreas naturais, ou seja, floresta e cerrado para implementação de áreas agrícolas e de pastagem. 